\title{
Role of microwave pre treatment in the extraction of high quality natural fibers
}

\section{Introduction}

Natural fiber has various applications throughout the world from ancient civilizations. Before, plant fiber was utilized for making garments, however now it has extensive ranges of applications from automotive to aviation industries. ${ }^{1,2}$ There are two types of natural fibers, such as plant origin and animal origin (cotton, linen, silk, wool etc.). The use of natural fibers as a replacement for synthetic fiber has more significance in the recent years due to its biodegradability. The major advantages of natural fibers are; low density, biodegradability and its market value which decide the quality of the final product in the market. Even though natural fibers can be used in place of synthetic fibers, it has one big disadvantage that they do not have same consistency in quality while considering synthetic fibers. The reason for the inconsistency may be due to different climatic conditions, crop varieties, efficiency of extraction process, and equipment used for processing Thomsen et al. ${ }^{3}$ Foulk et al. ${ }^{4}$ Plants with finest and long fibers can be harvested with low temperature and high relative humidity during growing season.

\section{Natural fibers}

Understanding the fiber structure is important to explain the role of microwave energy in order to obtain high quality fibers. The structure of natural fiber is non-uniform semi cylindrical and the diameter
Volume 2 Issue 2 - 2017

\author{
Gopu Raveendran Nair
}

Earth University, Costa Rica

Correspondence: Gopu Raveendran Nair, Earth University, Costa Rica, Email gopu.nair@mail.mcgill.ca

Received: June 04, 2017 | Published: July 06, 2017

of fiber reduces towards the end. Fiber always present as a bundle of 4-10 fibers sticks together. Baley ${ }^{5}$ Akin $^{6}$ and can be separated individually. Pectin presents in the plant stems/leaves serves as a glue to hold fibers together in bundles and the bundles to non-fiber tissues. ${ }^{7}$ Hemicelluloses, lignin and pectin form a matrix within the fiber bundle and cellulose plays the role of reinforcement to the matrix, which is the root cause of difficulty in fiber extraction. ${ }^{8}$ The cross section of flax and hemp stem is shown in Figure 1 as an example of natural fiber plants. In all natural fibers, cellulose contains about 50\% or more which provides strength to the fiber Nair et al. ${ }^{9}$ The chemical compositions of some of the natural fibers are shown in Table 1.

Table I Chemical composition of natural fibers Asim et al. ${ }^{10}$ Mohanty et al. ${ }^{18}$

\begin{tabular}{llllll}
\hline Type of fiber & Cellulose(\%) & Lignin(\%) & Hemi cellulose(\%) & Pectin(\%) & Ash(\%) \\
\hline Flax & $7 \mid$ & 2.2 & $18.6--20.6$ & 2.3 & --- \\
Kenaf & $31--57$ & $15--19$ & $21.5--23$ & --- & $2--5$ \\
Hemp & $57--77$ & $3.7--13$ & $\mid 4--22.4$ & 0.9 & 0.8 \\
Jute & $45--7 \mid$ & $12--26$ & $|3.6--2|$ & 0.2 & $0.5--2$ \\
Ramie & $68.6--9 \mid$ & $0.6--0.7$ & $5--16.7$ & 1.9 & --- \\
Pineapple leaf & $70-82$ & $4.4-6.06$ & 18 & $1.1--1.2$ & --- \\
\hline
\end{tabular}

Natural fiber production includes processes from harvesting of stems/leaves, pre-treatment (retting) of the harvested stems/leaves, drying, decortications or extraction of fibers and then directs to various industries depending upon the quality of the fiber. ${ }^{10}$ Among all the processes, the most important and energy consuming step is retting, which is the loosening of fibers from bundles and plant stem/ leaf wall Foulk et al. ${ }^{11}$ This pre-treatment could be done cautiously, because if the process is not optimum the quality of fiber will be affected. Over-retted fiber will be extremely thin, and under- retted fiber will be coarser and of lower quality. ${ }^{12}$

Two widely used methods of pre-treatment/retting of plant stems/ leaves are water retting and dew retting, where water retting is attained by immersing the leaves and stems inside water for relatively longer period of time from 1-3weeks. On the other hand, dew retting is the process of keeping the harvested plant in the field itself for about 2-3weeks. In both the cases, due to change in temperature and moisture, microorganisms attach the plants and break those strong covalent bonds (pectin bonds) and hence loosening the fibers. In water retting, anaerobic microorganisms attack the plant whereas in dew retting, aerobic microorganisms help to loosen the fibers. ${ }^{6}$ These methods are efficient in terms of the quality of fiber, but discontinued widely because of high pollution and contamination from the plant fermentation. Steam explosion and enzyme assisted separation of fibers are relatively newer methods and being used around the world in Figure $2 .{ }^{13}$ 


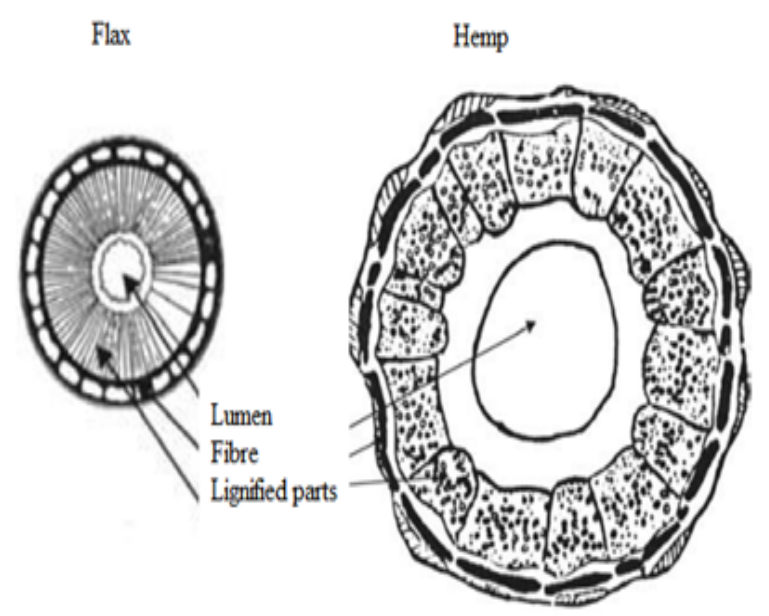

Figure I Cross section of flax and hemp stems Pallesan. ${ }^{12}$

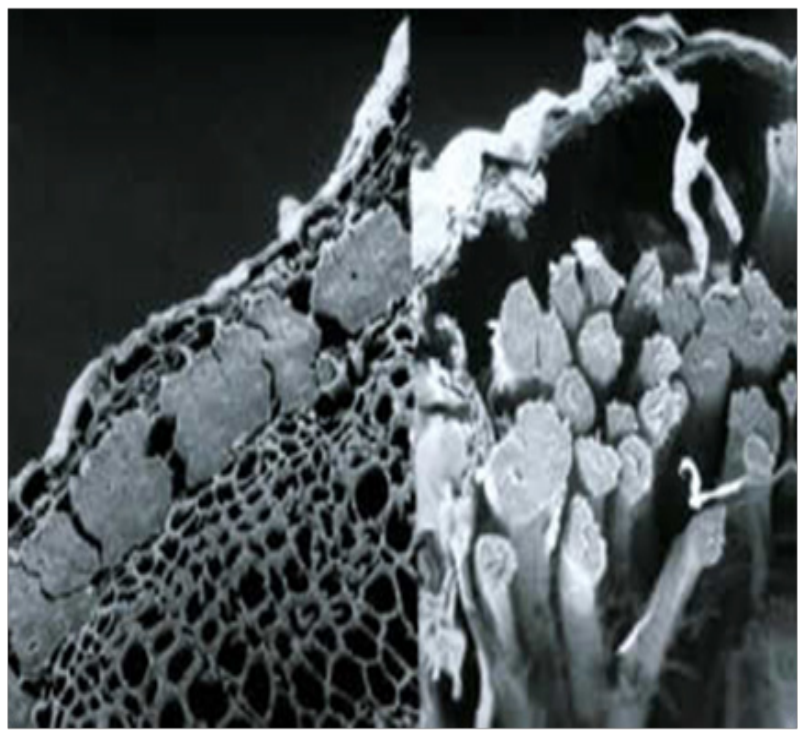

Figure 2 Scanning microscope images of non-treated flax stems demonstrates fiber bundles stick together and treated flax stems separated fiber bundles from non- fiber tissues Akin. ${ }^{6}$

\section{Role of microwave in fiber separation}

As mentioned, natural fibers are bound together and to the plant skin/bark by forming powerful pectin bonds. The pre-treatments are performed in order to degrade the non-fibrous tissues and strong bonds which in turns loosen the fiber bundles. The energy required to break a C-H bond of a pectin chain is found to be $413 \mathrm{KJ} / \mathrm{mol}$, however a microwave system at $2450 \mathrm{MHz}$ provide $1 \mathrm{~J} / \mathrm{mol}$. As we see there is a big difference in the required energy when compared to energy produced by a normal microwave generator Nutcher et al. ${ }^{14}$ However, it was proven that microwave energy is being used in biomass processing, irradiation, extraction etc. and the non- thermal effect of microwave in the main factor responsible for these processes Steel et al. ${ }^{15}$ Sridar ${ }^{16}$ In various chemical reactions, microwave energy is used for the pectin decomposition at relatively lower temperature ranges. ${ }^{17,18}$ The reason for the bond breakage is, when microwave energy is applied to a biomaterial, volumetric heating occurs due to the conversion of electromagnetic energy to mechanical and heat energy, which is due to dipole rotation. Apart from non- thermal effect of microwave, the separation of natural fibers is due to the thermal effect of microwave too, which can be explained by Maxwell's equation. The major property parameter of Maxwell's equation is the dielectric property of the material, which intensely influence the conversion of electromagnetic energy to thermal energy which in turn helps to separate natural fibers from the non-fibrous tissues. The dielectric property of a material is described by the complex relative permittivity ( $\varepsilon^{*}$ relative to that of free space) in the following relationship:

$$
\begin{aligned}
& \varepsilon^{*}=\varepsilon^{\prime}-j \varepsilon^{\prime \prime} \\
& \text { Where } j=\sqrt{-1}
\end{aligned}
$$

The real part $\varepsilon$ ' is the dielectric constant that reflect the ability of the material to store electric energy when in an electromagnetic field; the imaginary part $\varepsilon$ " is the dielectric loss factor that influence the conversion of electromagnetic energy into thermal energy. The ratio of the real and imaginary part of permittivity represents another important parameter tangent of loss angle $\left(\left(\tan \delta=\varepsilon^{\prime} / \varepsilon^{\prime \prime}\right)\right.$, which along with dielectric constant determines the attenuation of microwave power in heating. Therefore, thermal and non-thermal effects of microwave energy together help in the enhancement of fiber separation..$^{14}$ Basic awareness of fiber structure and its chemicals compositions is essential in the design of a microwave- assisted natural fiber separator in industry level. The objective of applying microwave energy into a plant stems/leaves to enhance the separation process by the breaking of the strong pectin bonds. As an evidence of non- thermal effect, Tsubaki and Azuma studied about microwave-assisted irradiation of biomass (on rice straw, bamboo and other fibrous plants), which proved that delignification accelerated above $180^{\circ} \mathrm{C}$ and released hemicellulose, initiated the breaking of bonds between lignin and carbohydrates. However, glass transition temperature of lignin (130$\left.200^{\circ} \mathrm{C}\right)$ is normally lower than that of cellulose $\left(230-250^{\circ} \mathrm{C}\right)$ and nearby that of hemicellulose $\left(160-200^{\circ} \mathrm{C}\right)$ under dry conditions. Glass transition temperatures of lignin and hemicelluloses unlike cellulose reduced at high moisture levels. This is the reason for soaking the stems/ leaves before microwave- assisted fiber separation. Since water is environmentally friendly and available, water is used as a solvent for microwave assisted treatment for the separation of natural fibers. ${ }^{17}$ The temperature levels of microwave- assisted fiber separation process can be optimized and kept at a lower level, otherwise the quality of fiber will be affected at higher level of temperature. ${ }^{9}$

\section{Conclusion}

Electromagnetic energy can be used in various biomass conversion processes such as lingo cellulosic conversion, extraction of nutrients, fiber release etc. Microwave and radio frequency are widely used for these treatments. Microwave/radiofrequency assisted natural fiber pre-treatment processes can be conducted at different frequencies/ wavelength of electromagnetic energy and other solvents in place of water.

\section{Acknowledgments}

None.

\section{Conflict of interest}

Author declares there is no conflict of interest in publishing the article. 


\section{References}

1. Akin DE. Linen most useful: perspectives on structure, chemistry, and enzymes for retting flax. ISRN Biotechnology, 2012. p. 1-23.

2. Nair R, Kurian J, V Yaylayan, et al. Microwave-assisted retting and optimization of the process through chemical composition analysis of the matrix. Industrial Crops \& Products. 2014;52:85-94.

3. Thomsen AB, Thygesen A, Bohn V, et al. Effects of chemical-physical pre-treatment processes on hemp fibers for reinforcement of composites and for textiles. Industrial Crops \& Products. 2006;24:113-118.

4. Foulk J, Akin D, Dodd R, et al. Production of flax fibers for biocomposites. Cellulose Fibers: Bio-and Nano-Polymer Composites. Berlin: Heidelberg, Springer; 2011. p. 61-95.

5. Baley C. Analysis of the Flax Fibers Tensile Behavior and Analysis of the Tensile Stiffness Increase. Composites-Part A: Appl Sci Manu. 2002;33:939-948.

6. Akin DE. Standards of Flax Fiber. ASTM Standardization News, USA: ASTM publication; 2005.

7. Van Sumere CF. Retting of Flax with special reference to enzyme retting. In: Sharma HSS, Van Sumere CF, editors. The Biology and Processing of Flax. M Publications, Belfast, Northern Ireland; 1992;153-193.

8. Thygsen LG, Bilde-Dorensen JB, Hoffmeyer P. Visualization of dislocations in hemp fibers-A comparison between scanning electron microscopy and polarized light microscopy. Industrial Crops \& Products. 2006;24:181-185.

9. Nair GR, Rho D, Yaylayan V, et al. Microwave assisted retting-A novel method of processing of flax stems. Bio systems engineering. 2013;116(4):427-435.
10. Asim M, Abdan K, Jawaid M, et al. A review on pineapple leaves fibre and its composites. International J Polymer Sci. 2015;1-16.

11. Foulk JA, Akin DE, Dodd RB. Processing Techniques for Improving Enzyme-Retting of Flax. Industrial Crops \& Products. 2001;13:239-248.

12. Pallesen BE. The quality of combine-harvested fiber flax for industrials purpose depends on the degree of retting. Industrial Crops and Products. 1996;5(1):65-78.

13. Adamsen AP, Akin DE, Rigsby LL. Chemical Retting of Flax Straw under Alkaline Conditions. Textile Research J. 2002;72(9):789-794.

14. Nüchter M, Ondruschka B, Bonrath W, et al. Microwave assisted synthesis-a critical technology overview Green Chem. 2004;6(3):128-141.

15. Steel BC, Bilek MM, McKenzie DR, et al. A technique for micro second heating and cooling of a thin biological sample. European Biophysics $J$. 2002;31(5):378-382.

16. Sridar V. Microwave radiation as a catalyst for chemical reactions. Current Science. 1998;74(5):446-450.

17. Tsubaki S, Azuma JI. Application of microwave technology for utilization of recalcitrant biomass. Advances in induction and microwave heating of mineral and organic materials, In Tech, Croatia; 2011. p. 697-722.

18. Mohanty AK, Misra M, Drzal LT. Surface modifications of natural fibers and performance of resulting bio composites: an overview. Compos Interface. 2001;8(5):313-343. 